\title{
NEW DEVELOPMENTS IN ARRAY TECHNOLOGY AND APPLICATIONS
}

Edited by A. G. DAVIS PHILIP, KENNETH A. JANES and ARTHUR R. UPGREN
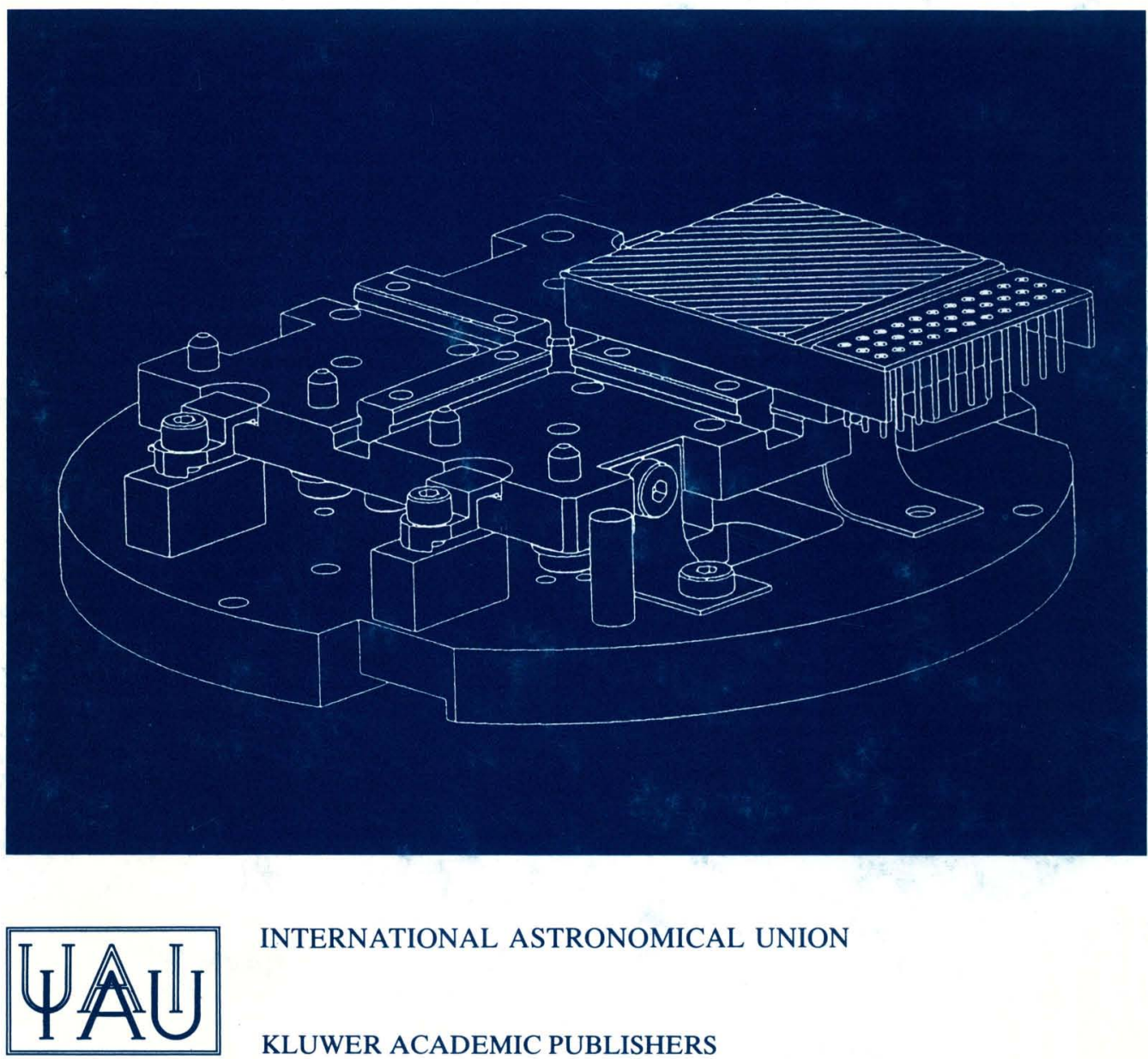

INTERNATIONAL ASTRONOMICAL UNION

KLUWER ACADEMIC PUBLISHERS 
NEW DEVELOPMENTS IN ARRAY TECHNOLOGY AND APPLICATIONS 


\title{
NEW DEVELOPMENTS IN ARRAY TECHNOLOGY AND APPLICATIONS
}

PROCEEDINGS OF THE 167TH SYMPOSIUM OF THE INTERNATIONAL ASTRONOMICAL UNION, HELD IN THE HAGUE, THE NETHERLANDS, AUGUST 23-27, 1994

\author{
EDITED BY \\ A. G. DAVIS PHILIP \\ Union College and the Institute for Space Observations \\ KENNETH A. JANES \\ Boston University \\ and \\ ARTHUR R. UPGREN \\ Van Vleck Observatory, Wesleyan University
}

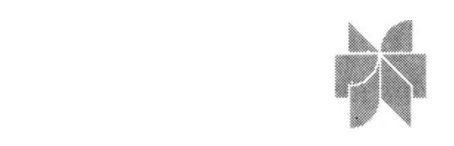

KLUWER ACADEMIC PUBLISHERS DORDRECHT / BOSTON / LONDON

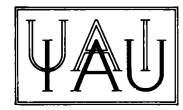


A C.I.P. Catalogue record for this book is available from the Library of Congress.

ISBN 0-7923-3639-9

Published on behalf of

the International Astronomical Union

by

Kluwer Academic Publishers, P.O. Box 17, 3300 AA Dordrecht, The Netherlands.

Kluwer Academic Publishers incorporates the publishing programmes of

D. Reidel, Martinus Nijhoff, Dr W. Junk and MTP Press.

Sold and distributed in the U.S.A. and Canadc.

by Kluwer Academic Publishers,

101 Philip Drive, Norwell, MA 02061, U.S.A.

In all other countries, sold and distributed

by Kluwer Academic Publishers Group,

P.O. Box 322, 3300 AH Dordrecht, The Netherlands.

\section{Printed on acid-free paper}

\section{All Rights Reserved \\ C1995 International Astronomical Union}

No part of the material protected by this copyright notice may be reproduced or utilized in any form or by any means, electronic or mechanical including photocopying, recording or by any information storage and retrieval system, without written permission from the publisher.

Printed in the Netherlands 

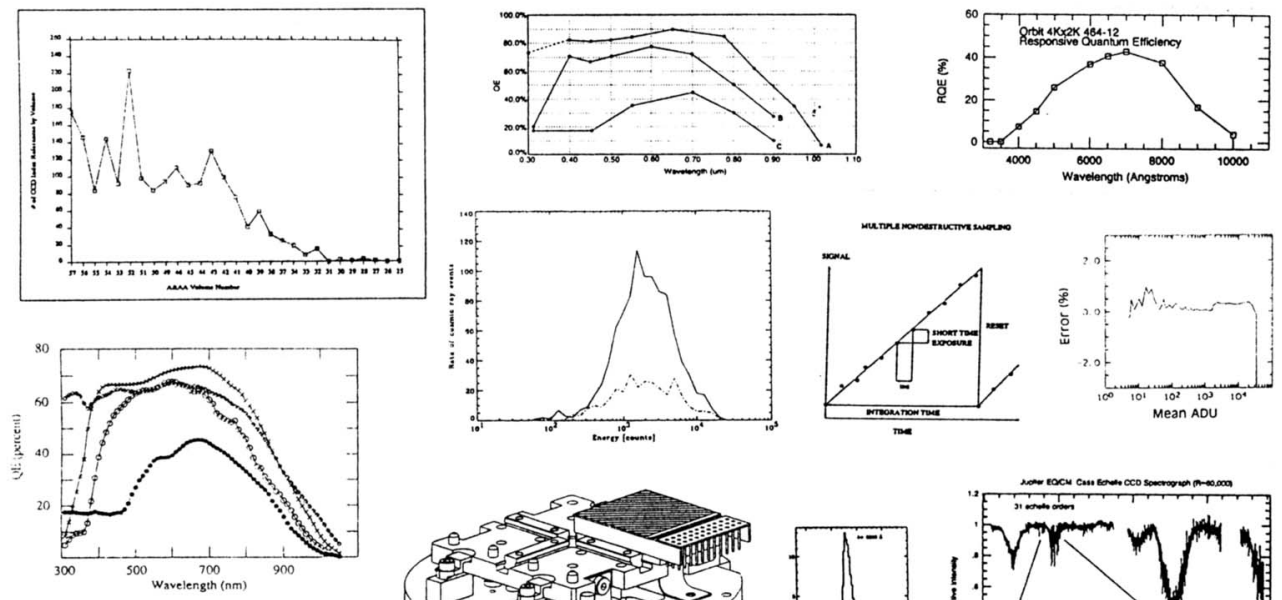

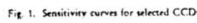
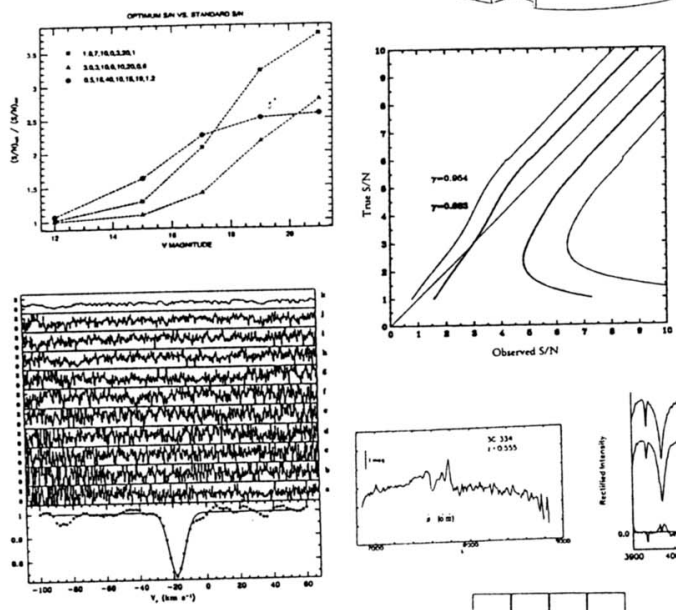

$\underline{M 1} \underline{\mathrm{S2}} \quad \underline{M 4}, \underline{M_{2}} \quad \underline{M 3}$
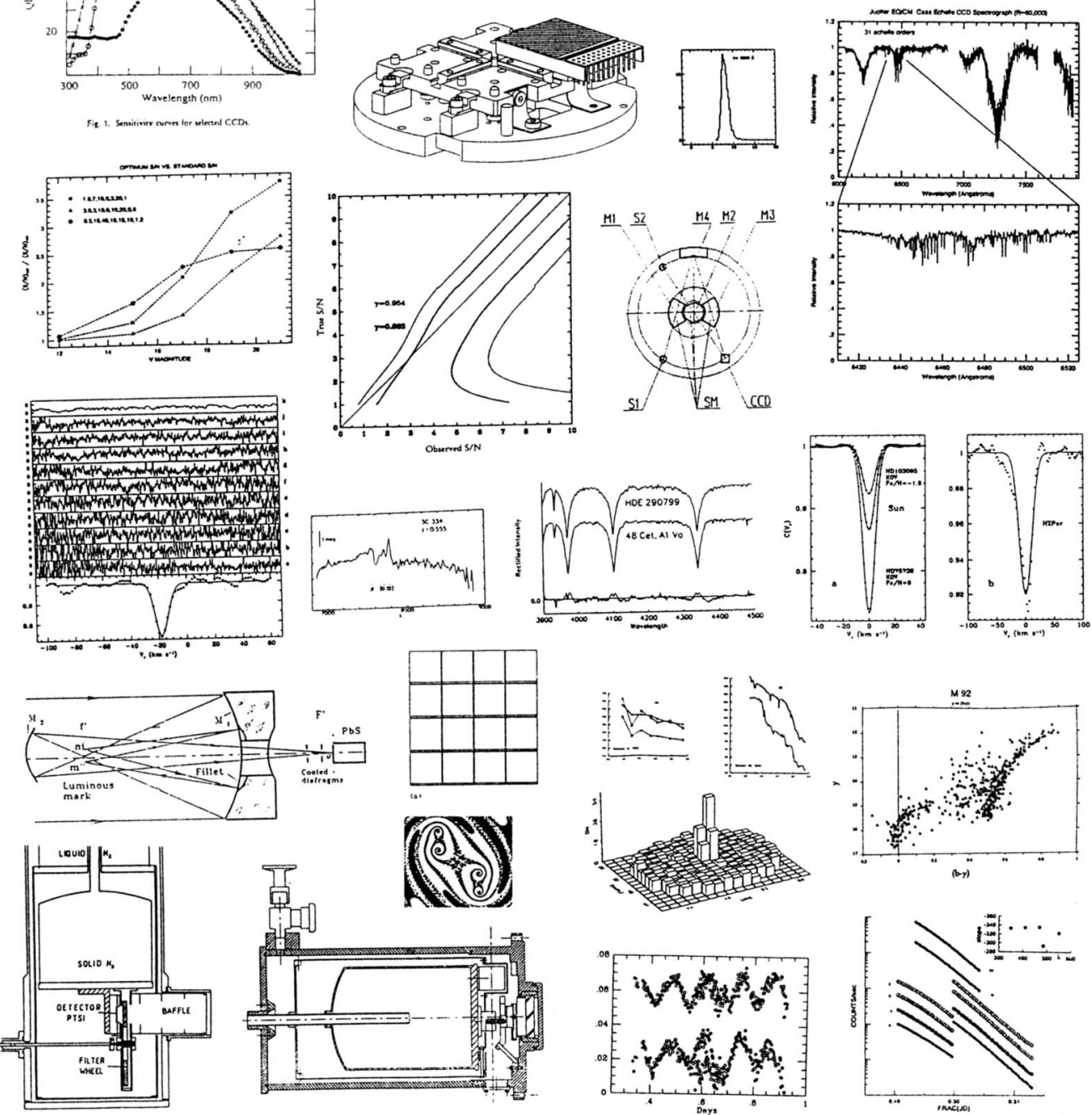

v 
Preface

$$
\text { Section I - Review Papers }
$$

INTRODUCTION

A. G. Davis Philip

ARRAY DETECTORS AND INSTRUMENTS FOR THE ESO VLT

Sandro D'Odorico

DESIGN AND FABRICATION OF LARGE CCDs FOR THE KECK OBSERVATORY DEIMOS SPECTROGRAPH

R. J. Stover, W. E. Brown, D. K. Gilmore and

M. Wei

SCIENTIFIC CCD PROSPECTS FOR 1994 AND BEYOND

Paul R. Jorden and A. P. Oates

NEW DEVELOPMENTS IN CCD TECHNOLOGY FOR THE UV-EUV SPECTRAL RANGE

Giovanni Bonanno

CCD CONTROLLERS

Robert W. Leach

CCDs IN ACTIVE ACQUISITION SYSTEMS

A. Blecha

CCD DEVELOPMENT ACTIVITIES AT ESO

O. Iwert

INFRARED ARRAY DETECTORS: PERFORMANCE AND PROSPECTS

Ian S. McLean 
viii

THE LICK OBSERVATORY TW'O MICRON CAMERA

K. Gilmore, D. Rank and P. Temi

INFRARED ARRAYS AT THE EUROPEAN SOUTHERN OBSERVATORY

G. Finger, G. Nicolini, P. Biereichel, M. Meyer and

A. F. M. Moorwood

THE IMPACT OF INFRARED ARRAY TECHNOLOGY ON ASTRONOMY

Giovanni G. Fazio

MONOLITHIC Si BOLOMETER ARRAYS: DETECTORS FOR FAR INFRARED AND SUBMILLIMETER DETECTION

Harvey Moseley

OBSERVATIONAL CONCERNS AND TECHNIQUES FOR HIGH-

BACKGROUND MID-INFRARED (5 - 20 micron) ARRAY IMAGING

Daniel Y. Gezari

AN INFRARED CAMERA BASED ON A LARGE PtSi ARRAY

I. S. Glass, K. Sekiguchi and Y. Nakada

109

PtSi IR ARRAY IN MOSAIC CONFIGURATION

Munetaka Ueno, Fumiaki Tsumuraya and

Yoshihiro Chikada

CCD PHOTOMETRY - PRESENT AND FUTURE

Alistair R. Walker

CCD PHOTOMETRY: SOME BASIC CONCERNS

C. Sterken

CHOOSING FILTERS TO MAKE CCD PHOTOMETRY TRANS-

FORMABLE TO OTHER DETECTORS

Andrew T. Young 
AUTOMATED CCD SCANNING FOR NEAR EARTH ASTEROIDS

Robert Jedicke

CCD TIME SERIES PHOTOMETRY OF ASTRONOMICAL SOURCES

Steve B. Howell

HIGH PRECISION STELLAR PHOTOMETRY WITH CCDs. I.

A. J. Penny

HIGH PRECISION STELLAR PHOTOMETRY WITH CCDs. II.

Michael S. Bessell

175

PRECISION DIFFERENTIAL CCD PHOTOMETRY

L. A. Balona

ARRAY POLARIMETRY AND OPTICAL-DIFFERENCING PHOTOMETRY

J. Tinbergen

197

COSMIC RAY EVENTS AND NATURAL RADIOACTIVITY IN

CCD CRYOSTATS

Ralph Florentin-Nielsen, Michael J. Andersen

and Sven P. Nielsen

MOCAM: A 4k X 4k CCD MOSAIC FOR THE CANADA-FRANCEHAWAII TELESCOPE PRIME FOCUS

J. C. Cuillandre, Y. Melliers, R. Murowinski,

D. Crampton, G. Luppino and R. Arsenault

ECHELLE SPECTROSCOPY WITH A CCD AT LOW SIGNAL-TO-

NOISE RATIO

Didier Queloz

NICMOS3 DETECTOR FOR SPECTROSCOPY

L. Vanzi, A. Marconi and S. Gennari

SPECTRAL CLASSIFICATION WITH ARRAY DETECTORS

C. J. Corbally 
SPECTROSCOPIC OBSERVATIONS OF SOLAR SYSTEM OBJECTS:

PUSHING THE LIMITS

$$
\text { Anita L. Cochran }
$$

"VA-ET-VENT" ("BACK-AND-FORTH") CCD SPECTROSCOPY: A NEW WAY TO INCREASE THE LIMITING MAGNITUDE OF VERY LARGE TELESCOPES

G. Soucail, J. C. Cuillandre, J. P. Picat and B. Fort

SOME PROBLEMS OF WIDE-FIELD ASTROMETRY WITH A SHORTFOCUS CCD ASTROGRAPH

$$
\text { I. S. Guseva }
$$

A DUAL CCD MOSAIC CAMERA SYSTEM SEARCHING FOR MASSIVE COMPACT HALO OBJECTS (MACHOs)

Kem H. Cook

MULTI-FIBER SPECTROSCOPY WITH WIDE-FIELD TELESCOPES

F. G. Watson

PERFORMANCE OF A $2048 \times 2048$ PIXEL THREE-SIDE-

BUTTABLE CCD DESIGNED FOR LARGE FOCAL PLANES

IN ASTRONOMY

$$
\text { J. A. Cortiula }
$$

CCD MOSAIC DEVELOPMENT FOR LARGE OPTICAL TELESCOPES

G. A. Luppino, M. R. Mezger and

S. Miyazaki

HIGHLIGHTS OF IAU SYMPOSIUM No. 167

Sandro D'Odorico 
Section II - Poster Papers

THE TRANSPUTER BASED CCD CONTROLLER AT ESO

Roland Reiss

DETECTOR CONTROLLERS FOR THE GALILEO TELESCOPE: A PROGRESS REPORT

G. Bonanno, P. Bruno, R. Consentino, F. Bortoletto, M. D'Alessandro, D. Fantinel, A. Balesstra and

P. Marcucci

THE RUTHERFORD-SAAO CCD CONTROLLERS AND THEIR APPLICATIONS

I. S. Glass, D. B. Carter, G. F. Woodhouse, N. A. Waltham and G. M. Newton

CCD IMAGERS WITH ENHANCED UV SENSITIVITY FOR INDUSTRIAL AND SCIENTIFIC APPLICATIONS

G. I. Vishnevsky, M. G. Vydrevich, L. Yu. Lazovsky, V. G. Kossov and S. S. Tataushchikov

THE LARGE-FIELD BRIGHT-STAR HIGH-PRECISION CCD PHOTOMETER OF BAO

Shiyang Jiang

EFFECTS OF SHUTTER TIMING ON CCD PHOTOMETRY

D. Galadi-Enriquez, C. Jordi and E. Trullols

ASTRONOMICAL APPLICATIONS OF CCDs IN HUNGARY: THE FIRST STEPS AND FUTURE PLANS

G. Szécsényi-Nagy

A SIMPLE CCD-SYSTEM FOR SECONDARY ALIGNMENT OF THE SPECTRUM-UV SPACE TELESCOPE

V. Didkovsky, N. V. Steshenko, P. I. Borzyak and A. I. Dolgushin 
THE MODERNIZATION OF THE PULKOVO PHOTOGRAPHIC (PHOTOELECTRIC) VERTICAL CIRCLE BY A CCD ARRAY

G. A. Goncharov, B. K. Bagildinsky, E. V. Kornilov,

D. D. Polojentsev, K. V. Rumyantsev and V. D. Shkutov 333

A NEW OCULAR MICROMETER FOR THE MAHIS

T. R. Kirian, V. S. Korepanov and V. M. Grozdilov 335

PbS AND CCD ARRAY AUTOCOLLIMATION MICROMETERS

FOR THE INFRARED MERIDIAN CIRCLE

V. N. Yershov

THE NOAO CCD CONTROLLER - ARCON

Alistair R. Walker

INTENSIFIED ELECTRON-BOMBARDED CCD IMAGES FOR

INDUSTRIAL AND SCIENTIFIC APPLICATIONS

I. Dalinenko, G. Vishnevsky, V. Kossov, L. Lasovsky,

G. Kuzmin and A. Malyarov

THE CCDs AT ESO: A SYSTEMATIC TESTING PROGRAM

T. M. C. Abbott

DEVELOPMENT OF A 7000 x 4000 PIXEL MOSAIC CCD CAMERA

Nobunari Kashikawa, Masafumi Yagi, Naoki Yasuda, Sadanori Okamura, Kazuhiro Shimasaku, Mamoru

Doi and Maki Sekiguchi

THE FEASIBILITY OF A CCD FOR AN ASTROMETRIC REFRACTOR

A. R. Upgren, Alice Morales, Jose Herrero, J. W.

Griese, III, J. M. Vincent and John T. Lee

STELLAR POSITIONS FROM CCD IMAGES

A. R. Upgren, C. Abad and J. Stock 
ON THE ACCURACY OF CCD AND PHOTOGRAPHIC OBSERVATIONS OF ASTEROIDS AND THEIR CURRENT ORBIT DETERMINATIONS

$$
\text { O. P. Bykov }
$$

ON THE PROBLEM OF STANDARD FIELDS FOR CCD ASTROMETRY

COMBINED VISUAL AND NEAR-IR DIGITAL PHOTOMETRY: THE VERY YOUNG CLUSTER WESTERLUND 2

M. D. Guarnieri, M. Gai, G. Massone,

M. G. Lattanzi, U. Munari and A. Moneti

A DUAL CCD MOSAIC CAMERA SYSTEM SEARCHING FOR MASSIVE-COMPACT HALO OBJECTS (MACHOs)

Kem H. Cook

JHK PHOTOMETRY OF EXTRAGALACTIC SOURCES USING AN INFRARED ARRAY CAMERA

I. S. McLean, T. Liu and H. Tepliz

PRECISION CCD PHOTOMETRY OF THE HORIZONTAL BRANCH

A. G. Davis Philip

CCD PHOTOMETRY OF THE M 67 CLUSTER IN THE VILNIUS PHOTOMETRIC SYSTEM

R. Boyle, V. Straižys, F. Vrba,

F. Smriglio and A. Dasgupta

ESTIMATION OF THE ERRORS INVOLVED IN THE INTENSITY MEASUREMENT OF LOW S/N RATIO EMISSION LINES

Claudia Rola and Didier Pelat

EEV AND ELECTRON CORP. VIRTUAL PHASE CCDs IN THE NEAR IR REGION, He $\lambda 10830 \AA$

A. G. Shcherbakov, Z. A. Shcherbakova, I. Ilyin and I. Tuuominen 
xiv

STELLAR PHOTOMETRY WITH A PERFECT CCD

Bjarne Thomsen and Frank Grundahl Jensen

APPLICATIONS OF A REALISTIC MODEL FOR CCD IMAGING

Steve B. Howell and William J. Merline

3D: THE NEW NEAR-INFRARED FIELD IMAGING SPECTROMETER

L. E. Tacconi-Garmen, L. Weitzel, M. Cameron, S.

Drapatz, R. Genzel, A. Krabbe, H. Kroker and

N. Thatte

TECHNICAL CCD SYSTEMS FOR THE ESO VERY LARGE TELESCOPE

J. Erich

POSTER DISCUSSIONS

377

INDEX

NAME INDEX

OBJECT INDEX

SUBJECT INDEX

390 